\title{
The United States and China: Deadlocks and Paradoxes of Trade War
}

\author{
A. I. Salitskii ${ }^{a, *}$ and E. A. Salitskaya ${ }^{b, * *, \#}$ \\ ${ }^{a}$ Primakov Institute of the World Economy and International Relations, Russian Academy of Sciences, Moscow, Russia \\ ${ }^{b}$ Bauman Moscow State Technical University, Moscow, Russia \\ *e-mail:sal.55@mail.ru \\ **e-mail: e.salitskaya@yandex.ru
}

Received March 20, 2020; revised April 5, 2020; accepted April 23, 2020

\begin{abstract}
The current relations between the United States and China, which are largely defined by the phrase trade war, are analyzed. The authors place an emphasis on the economic, political, and legal aspects of these relations and the direct and indirect consequences of the trade war for both its participants and the world community. Attention is focused on the first months of 2020, when, in particular, a trade and economic agreement was signed between the parties. Individual sections of the agreement are considered, including those related to intellectual property; the promotion of American medicines to the Chinese market; and China's obligations to purchase American manufactured goods, agricultural products, and fuels.

A brief excursion into the history of the trade war is undertaken, the position of the parties is shown, and key problems of the dialogue are identified. New factors affecting this dialogue are considered: the recession that has begun in the global economy and the emergence and spread of the coronavirus epidemic. The actions of the parties to respond to the new challenges are evaluated.
\end{abstract}

Keywords: China, United States, D. Trump, Xi Jinping, global economy, international relations, US-China relations, trade war, economic sanctions, Chinese exports, COVID-19 pandemic.

DOI: $10.1134 / \mathrm{S} 101933162004005 \mathrm{X}$

The beginning of 2020 was rich in unexpected events in the global economy and politics. The outbreak of coronavirus infection became especially noticeable among them, expanding from China to many Asian and Western countries. It contributed to the vivid manifestation of the most characteristic features of their foreign and domestic policies, exposed many old social diseases, and led to the aggravation of long-standing and relatively new contradictions. A sense of anxiety grew rapidly in the public mind, and the pages of the media and scientific editions were filled with forecasts of various kinds of crises, both ongoing and expected. It became commonplace to recognize the inadequacy of the existing mechanisms of managing the economy and international relations at the global, regional, and country levels, and many political leaders were subjected to well-deserved and undeserved criticism.

\footnotetext{
\#Aleksandr Igorevich Salitskii, Dr. Sci. (Econ.), is Chief Researcher of the Primakov Institute of the World Economy and International Relations, RAS (IMEMO RAS). Elena Aleksandrovna Salitskaya, Cand. Sci. (Law), is an Associate Professor in the Intellectual Property Department and Head of the Department for Legal Support of Intellectual Property at the Center of Intellectual Property of the Bauman Moscow State Technical University.
}

In the first months of 2020 , special attention was focused on two leading world powers: China and the United States, the relations between which have been extremely unproductive since D. Trump's administration came to power. The trade war initiated by Washington affected not only the economies and policies of both states but also the global business climate, forcing authoritative observers to question the strength of the world order that had developed by the end of the second decade of the 21 st century and to consider the need for its cardinal change.

In the considerations offered to the reader, which rely on the material of US-China relations in the second half of the 2010s, we will try to reveal differences in the approaches of the two countries to their relations and current world problems and motives and positions of various participants in this interaction. The starting point of the analysis will be the events of 2020 with necessary excursions into history.

\section{THE JANUARY AGREEMENT OF THE PARTIES}

On January 15, 2020, an agreement of the so-called first phase between the parties (hereinafter, the Agree- 
ment) was signed in Washington [1]. For the United States, it was signed by President Trump, and for China, by Deputy Prime Minister Liu He, who is also a member of the Politburo of the CPC Central Committee.

The parties moved toward this compromise over quite a long time. During the years of Trump's presidency, the White House and Congress drew up an impressive documentary and legal base of pressure on China. It all started with the adoption of the National Security Strategy in December 2017 (which defined China as a "revisionist power") [2], and in March 2018 , the president approved an investigation by the US trade representative into China based on the Trade Act of 1974 [3]. This line was continued by a report of the Trade and Manufacturing Council [4], led by the ideologist of the trade war against China P. Navarro, and two annual reports of the US trade representative to Congress on China's WTO compliance [5, 6]. Restrictions were imposed on investors from China [7]. Bulletins and annual reviews of the Congress US-China Economic and Security Review Commission were regularly published.

These documents charge China with numerous sins. They include dishonest commercial practice, restrictions on the access of foreign business to the domestic market, economic aggression, and subsidizing state enterprises. China is accused of theft of technology and intellectual property worth hundreds of billions of dollars a year (!), cyber espionage, and fentanyl shipments to the United States. Particularly condemned are the harmful "state-directed mercantilism," leading to a huge loss of jobs in American industry, and the manipulation of the exchange rate. In addition, Washington condemns Beijing for its plans on scientific and technological development, including the Made in China 2025 program, adopted in 2015 and containing guidelines in import substitution and access to the world market of advanced technologies. It is stated that China's actions have caused serious damage to other WTO members and the multilateral trading system, which was not designed to interact with a nonmarket economy of such proportions; it is proclaimed that the United States will take necessary measures to curb Chinese policy even if they do not fit into the WTO rules.

Faced with such a fierce attack from the United States, which in the spring and summer of 2018 led to sanctions against the Chinese company ZTE and increased duties on goods imported from China with a total value of $\$ 50 \mathrm{bln}$, Beijing responded with a symmetric increase in tariffs on American goods. In the early autumn of 2018, the Chinese government's reaction to the charges followed, which was generally sustained in a peaceful manner with numerous illustrations of the parties' mutually beneficial economic cooperation [8]. At occasional meetings of representatives of the parties (negotiations in the framework of permanent bilateral formats had been stopped at the initiative of the Americans), China made it clear that it was ready to solve the problem of trade imbalance through additional purchases of goods from the United States.

At a meeting of the leaders of the two countries in Argentina at the end of 2018, it was decided to resume the ongoing negotiation format with a view to reach an agreement. However, by May 2019, the negotiations, which had taken 11 rounds, had not led to any agreement, and each party blamed the other for this failure. There was an exchange of new additional tariffs; in addition, the United States announced sanctions against the Chinese company Huawei in the form of a ban on the supply of microchips to it by American manufacturers. The US Department of Commerce's blacklist included many other Chinese companies and individuals, about 150 in total.

At the end of June 2019, at a meeting in Osaka, Trump and $\mathrm{Xi}$ agreed on a twelfth round of negotiations, but it did not lead to tangible results either. In early August, the American president brought down a new package of duties on China and tightened it even more after the subsequent asymmetric-for a smaller amount-response from Beijing. The conflict reached its climax.

In September-October, the parties began to take their first steps towards each other: tariff exemptions were announced for some important commodity items and deferrals in the introduction of new duties. At the beginning of October, the thirteenth round of negotiations took place; the parties managed to agree only on continuing work on the agreement, breaking it into phases. In mid-December, consensus was announced on the first phase. Washington agreed not to introduce new tariffs on $\$ 160$ bln of imports from China from December 15 , as well as to halve (up to $7.5 \%$ ) the $\$ 120$ bln tariffs introduced in September 2019. Note that 25 -percent tariffs on imports from China for $\$ 250 \mathrm{bln}$ will be preserved after the signing of the agreement, which makes it clearly asymmetric.

At the same time, Beijing outlined the limit of concessions: on systemic issues, i.e., regarding state participation in the economy, it will not compromise. Characteristically, on November 22, the People's Daily published an article by Liu He, in which he emphasized that China would continue to strengthen and develop the public sector of the economy.

After a short revision, on January 15, 2020, the agreement was signed. It contains six chapters, including intellectual property, technology transfer, trade in food and agricultural products, financial services, macroeconomic policies and exchange rate matters, and trade expansion. A permanent bilateral dispute resolution mechanism was envisaged.

The first chapter contains the obligations of the parties in the field of intellectual property. In particular, it provides for the protection of confidential busi- 
ness information, including trade secrets; processes, styles, and methods of work; transactions; logistics; and data on customers, inventories, profits, and losses and expenses, as well as any other information of commercial value. The parties undertake on a reciprocal basis to make steps against violations, including amending legislation. The burden of proof in cases of illegal acquisition of trade secrets in accordance with the Agreement lies with the defendant. The parties also agreed on quick preventive measures against the illegal acquisition of trade secrets. They also agreed that the plaintiff should not provide information on losses as a prerequisite for starting proceedings on illegal acquisition of trade secrets. In addition, China undertakes to prohibit the disclosure of confidential information and trade secrets by administrative authorities and to limit their requirements on business concerning the provision of such information. A special clause of the Agreement provides for nondisclosure of commercial information related to pharmaceutical products. Measures are also stipulated on early settlement of disputes on patents and the elimination of unreasonable delays in their consideration. Certain subchapters relate to measures for the prevention of the spread of piracy and counterfeiting in online trading, the protection of copyright and geographical indications in trademarks, the destruction of counterfeit products, etc.

Issues on intellectual property reflected in the Agreement include the following: "Trade Secrets and Confidential Business Information" (Section B), "Pharmaceutical-Related Intellectual Property" (Section C), "Patents" (Section D), "Piracy and Counterfeiting on E-Commerce Platforms" (Section E), "Geographical Indications" (Section F), "Manufacture and Export of Pirated and Counterfeit Goods" (Section G), "Bad-Faith Trademarks" (Section H), "Judicial Enforcement and Procedure in Intellectual Property Cases" (Section I), and "Bilateral Cooperation on Intellectual Property Protection" (Section J).

Note that the chapter on intellectual property is not structured according to the type of protected objects, which is characteristic of both most national laws and international treaties (for example, the second part of the Agreement on Trade-Related Aspects of Intellectual Property Rights (TRIPS) [8]), but rather with regard to the scope of protected economic interests. By object, only the sections on trade secrets and confidential business information, patents, geographical indications, and trademarks are singled out. However, here, too, the character of the object is quite arbitrary. Thus, in the section designated as "Patents," almost exclusively patents in the pharmaceutical field (more precisely, the extension of their validity period if there were unjustified delays in granting a patent or permission to put the drug on the market) are considered, while inventions in other sectors of the economy are not mentioned.
The separation of issues on the protection of trade secrets and confidential information as an independent section is undoubtedly logical and is based on the feature of the object. Note, however, that, from a legal point of view, this category of objects is rather obscure. Unlike inventions, which are protected by patent rights, trade secrets do not have a single, universally accepted protection regime; moreover, not all jurisdictions recognize them as an object of intellectual property rights, ${ }^{1}$ let alone the possibility of a fairly broad interpretation of the concept of confidential business information. Most likely, the respective provisions of the Agreement are derived from US national law, where the concepts of both trade secrets and confidential business information have legislative definitions (the former, in the Defend Trade Secrets Act of 2016 [10] and the latter, in $\$ 201.6$ of the US Code of Federal Regulations [11]) and are provided with legal protection. In China, there is no independent law on trade secrets; at the sublegislative level, the document Several Provisions on Prohibiting Infringements upon Trade Secrets [12] has been adopted, designed to enforce the Law of the People's Republic of China Against Unfair Competition [13].

The definition of confidential business information included in the Agreement almost completely duplicates the definition of the corresponding concept in US law. This is not surprising: the clauses of the Agreement relating to intellectual property look like an attempt to introduce certain provisions of American law into Chinese national law. This is evidenced by the very construction of most of the articles of the first chapter: a declaration that the parties undertake to protect any rights and interests - the obligation of China to introduce specific legal norms in the relevant field-a guarantee on the part of the United States that the normative conditions effective on its territory provide a legal regime equivalent to that envisaged in the article.

The structure of the Agreement's chapter dedicated to intellectual property is much more determined by the spheres of economic interests than by the features of the legal nature of various objects. Whose interests are meant? Obviously, both the intention to incorporate the norms of the US national legislation into the legal system of the PRC and the aspects of intellectual property chosen for settlement in the Agreement reflect the interests of the American party. Thus, two sections of the Agreement are designed to ensure the rights of pharmaceutical companies-a sector that today is certainly more developed in the United States. In 2019, the United States ranked seventh in the world in exports of pharmaceutical prod-

\footnotetext{
${ }^{1}$ For example, under Russian law, trade secrets are not intellectual property in the legal sense of the term. Intellectual rights to information constituting a trade secret arise only if information constituting a production secret is protected in a trade secret mode (about the concept of a production secret, see article 1465 of the Civil Code of the Russian Federation [9]).
} 
ucts, while China is not among the 15 leading states by this indicator [14].

The protection of trade secrets and other confidential information is also primarily a concern of American companies operating in the Chinese market, which are afraid, in particular, of the disclosure of such information as a result of actions by China's authorized state bodies. This issue is covered by article 1.9 of the Agreement, which prohibits the disclosure of trade secrets and other confidential information by the administrative authorities of China and obliges them to limit their business requirements on the provision of relevant data.

There is no doubt that the provisions on countering piracy and counterfeiting on e-commerce platforms serve the interests of the United States. It is no secret that at present observance of intellectual rights on popular trading platforms such as AliExpress is extremely conditional. Moreover, while previously Chinese manufacturers were mainly accused of violating trademark rights, now the emphasis is shifting towards copyright and industrial design rights: refusing to place famous brand symbols on their products, Chinese manufacturers at the same time are actively borrowing product models themselves, creating highly accurate replicas of original products. Sections $G$ and $\mathrm{H}$ of the Agreement on the production and exports of pirated and counterfeit goods and the unfair use of trademarks continue the line of counteraction to the production and exports of cheap products that copy products of well-known brands.

We are bound to conclude that the first chapter of the Agreement, dedicated to intellectual property, is not only based on legal regulations in force in the United States but also aims to ensure the economic interests of this party. Time will tell whether this will allow the United States to approach victory in the trade war, which will inevitably shift progressively to the sphere of technology and rights to intangible assets.

The second chapter of the Agreement addresses technology transfer issues. It is indicated, in particular, that the parties should not require the transfer of technology in connection with obtaining permits for investment and the establishment of joint ventures, as well as disclose confidential technical information during various administrative procedures.

Chapter 3 is dedicated to trade in food and agricultural products. The General Administration of Customs of the PRC and the US Food and Drug Administration are committed to taking steps to remove restrictions on the imports of dairy products from China to the United States in connection with the discovery of melamine in them. The terms and procedure for checking the quality, sanitary condition, standardization, and certification of American dairy products for export to China are determined. Similarly, exports to China of American chicken, beef, breeding cattle, pork, meat products, aquaculture products, rice, potatoes, nectarines, blueberries, avocados, barley, alfalfa, food additives, animal feed, pet food, etc., are agreed. The Agreement also provides for the US response to imports of the PRC's agricultural products, including bonsai, pears, citrus fruits, jujube, etc. The parties also agreed on the optional sanitary control for trade in frozen fruits and vegetables.

The fourth chapter deals with mutual access to the financial services market. It refers to depository and surety operations in the stock markets, the activities of rating agencies, and requirements on the capital of foreign branches. It also specifies admission to the markets of both countries for electronic payment operators, as well as asset management companies.

In the fifth chapter, the United States and China reaffirm their commitment to refrain from competitive devaluations of national currencies, regularly exchange information on the balance of payments and foreign exchange reserves, and publish data in a timely manner on exports and imports of goods and services.

The most noteworthy part, which is almost unprecedented in the history of international trade, is the sixth chapter of the Agreement, which sets out China's obligations to purchase goods and services from the United States in 2020-2021. These obligations are grouped into four categories and are specified in the annexes to the Agreement.

The first category includes US manufacturing goods, which China pledges to purchase $\$ 32.9$ bln more in 2020 than in 2017, and in 2021 it is planned to purchase such goods $\$ 44.8$ bln above the baseline 2017 amount. This group includes microchips, the largest item of Chinese imports. Agricultural goods belong to the second category; the Chinese will buy them in 2020 by $\$ 12.5$ bln more than in 2017, and in 2021, by $\$ 19.5 \mathrm{bln}$. The third category is energy products, the agreed increments being $\$ 18.5 \mathrm{bln}$ and $\$ 33.9 \mathrm{bln}$. Finally, the fourth category is comprised of services, which the Chinese promised to buy at least $\$ 12.8$ bln and $\$ 25.1$ bln above the 2017 baseline, respectively. The total amount is quite impressive: the increase in imports of American goods and services to China in 2020 will amount to $\$ 76.7$ bln, and $\$ 123.3$ bln in 2021 . The total for two years is $\$ 200$ bln (approximately $5 \%$ of two-year Chinese imports).

The agreement contains article 7.2 with a reservation about force majeure circumstances, which were not long in coming: in the first quarter of 2020, the planet suffered the coronavirus pandemic. Therefore, it is obvious that part of the agreement, especially its sixth chapter, will still be discussed and adjusted by the parties. In the meantime, note one of the paradoxes of modern relations between China and the United States. Washington goes beyond the framework of its own system of regulating international trade and exerts strong pressure on a large developing country, insisting actually on becoming its fuel and food appendage. 
Table 1. China's trade with the United States in 2015-2019, bln dollars

\begin{tabular}{l|c|c|c|c|c}
\hline \multicolumn{1}{c|}{ Indicators } & 2015 & 2016 & 2017 & 2018 & 2019 \\
\hline US imports & 482 & 463 & 505 & 562 & 492 \\
PRC imports & 149 & 134 & 154 & 155 & 123 \\
Trade balance & 333 & 329 & 351 & 407 & 369 \\
\hline
\end{tabular}

Compiled according to the customs of China and the United States.

\section{DIRECT AND INDIRECT EFFECTS OF THE TRADE WAR}

The exchange of the first packages of duties in the summer of 2018 did not have any serious impact on China's exports to the United States, which continued to grow and increased by $11.3 \%$ over the year. US imports to China turned out to be more sensitive in the same year and stagnated.

The increase in tariff pressure on China in 2019 was more effective in terms of protecting the US market. By the beginning of 2020, China-US trade had already suffered very noticeable losses: China's exports in 2019 decreased by $12.5 \%$, and imports, by $20.9 \%$ (Tables 1,2 ). At the same time, the flow of direct investment from China to the United States began to decline. From $\$ 47$ bln in 2016, the investments fell to $\$ 30$ bln in 2017 and did not exceed $\$ 5$ bln in the next two years. Moreover, in 2019, massive sales of Chinese assets in the United States began, both of legal entities and individuals [15].

The significant changes, primarily the sharp decline in Chinese exports, affected China-US trade in the first quarter of 2020. However, they were not so much a result of the trade war but rather a consequence of deep shocks in economic life caused by the fight against COVID-19 (Table 2). Note, however, that China, despite strict quarantine measures, tried to fulfill its obligations for the purchase of American products defined by the Agreement, increasing, in particular, the imports of American LNG and agricultural goods. In the first quarter of 2020, the imports of soybeans doubled (up to $7.8 \mathrm{mln}$ tons), the imports of pork increased six times (up to $168000 \mathrm{t}$ ), and cotton imports, by $43 \%$ (up to $125000 \mathrm{t}$ ).

It is noteworthy that the trade war with the United States did not have a noticeable negative impact on the investment climate in China. In both 2018 and 2019, the inflow of foreign direct investment continued to increase, their growth amounting to 3 and $2.4 \%$, respectively. Among the well-known American corporations that began large-scale investment projects in China were Tesla, Exxon Mobil, Apple, Micron Technology, and many others.

One can also state that the trade aggression launched by Trump's cabinet against China, without having a strong influence on the economy and foreign economic relations of the Celestial Empire, has brought very modest results in terms of increasing employment in the United States (even if we agree that such a relationship does exist). In March 2010 (the lowest point after the crisis of 2008-2009), employment in the manufacturing industry reached $11.453 \mathrm{mln}$ people; by the time when Trump came to power in February 2017, this figure had grown to $12.384 \mathrm{mln}$, amounting to $12.839 \mathrm{mln}$ in March 2020 [16]. In other words, about 400000 new jobs appeared in the manufacturing sector under Trump by the spring of 2020 (i.e., over almost four years), while under his predecessor this figure had been 330000 within two years and a half. Note that a significant part of this increase under Trump was related to the processing of cheaper oil and natural gas-the production of plastics, synthetic fibers, etc., against the backdrop of a slowdown in automation and robotization in American industry.

At the same time, Trump's trade war against China had a noticeable indirect negative impact on the entire situation in the global economy and trade, sowing confusion and pessimistic sentiment among investors. According to most analysts, the trade war between the two leaders of the global economy was one of the causes of the gradual slide of the world economy into recession in 2020. In 2019, the growth rate of exports and GDP of almost all East Asian countries decreased significantly; this trend was especially noticeable in the second half of the year. Economic growth also slowed in Europe, as well as in the United States itself. In the last quarter of 2019, there was a negative GDP growth in Japan and Hong Kong. The COVID-19 pandemic against the backdrop of the weakening economic dynamics sharply worsened the situation in the world economy.

The data on the geographical distribution of China's foreign trade in the first quarter of 2020 , released in mid-April, indicated a difficult situation both in China and in partner countries (Table 3).

Table 2. Reduction in China's trade with the United States in 2019-2020 on an annualized basis, \%

\begin{tabular}{l|c|c|c}
\hline \multicolumn{1}{c|}{ Indicators } & January-March 2019 & January-December 2019 & January-March 2020 \\
\hline PRC exports & -8.5 & -12.5 & -25.2 \\
PRC imports & -31.8 & -20.9 & -3.7 \\
\hline
\end{tabular}

Compiled according to the customs of China. 
Note, however, that the ASEAN countries remained the only and therefore especially valuable example of maintaining positive dynamics in trade with China. It is worth mentioning that, in general, Chinese exports suffered much more significant losses than imports, which allowed China's partners to improve their currency situation slightly.

It would seem that such a situation should have caused concern in Beijing (the country's trade balance in the first quarter of 2020 was drawn up with a minimal positive surplus but turned out to be negative in the first two months), but there are no signs of this. First, the country's foreign exchange reserves remain very significant, and, second, the negative balance in trade in international services is decreasing, the balance being mainly formed by the expenditures of Chinese tourists abroad; in addition, the decline in oil and natural gas prices in the world market is also to the benefit of China. The shrinking asset in trade with the United States makes it possible to count on more favorable conditions for normalizing ties with the hegemon after overcoming the consequences of the pandemic-of course, if Washington understands the need for a compromise.

Apparently, the rearrangement of global value chains (GVCs) in the Asian region, which has continued with renewed vigor, should be viewed as an indirect consequence of the Unites States' trade war against China. Some of the labor-intensive and assembly plants are being removed from China to the countries of Southeast and South Asia, from where the finished products continue to go to the markets of the United States and Europe. In some cases, the chains of manufacture of certain products are locked on sales in the Asian countries themselves. An indirect indicator of this process is perhaps the reorientation of Hong Kong exports to Asian countries-from $54 \%$ in 2000 to $76 \%$ in 2018, with a decrease in the share of North America from 26 to $9 \%$ over the same period [17, p. 150]. It is becoming obvious that China's dependence on the exports of finished goods to the United States is not so critical and, moreover, is superable. This, of course, does not mean refusing to work for the American consumer; in the last two years, various roundabout maneuvers for the supply of Chinese goods to the United States have sharply intensified. Assembly stages of export production are being moved abroad: to Bangladesh, Vietnam, Malaysia, the Philippines, and Taiwan. Transfer price mechanisms are being involved, and the diffusion of exports to targeted (and duty-free) delivery of goods to the American end consumer is being used [18].

Finally, there is no doubt that over time, Trump's trade war against China will begin to annoy the public and irritate business, which in general is not disposed to returning jobs from China to the United States: this is an expensive and risky venture. Such a reshoring is now hindered by the spread of the pandemic in the
Table 3. China's foreign trade in the first quarter of $2020, \%$ of the first quarter of 2019

\begin{tabular}{l|c|c}
\hline Trading partners & PRC exports & PRC imports \\
\hline Total & -13.3 & -2.9 \\
EU (27) & -16.0 & -7.0 \\
Britain & -26.5 & -8.3 \\
United States & -25.2 & -3.7 \\
ASEAN & 0.4 & 8.4 \\
Japan & -16.0 & -4.7 \\
South Korea & -11.3 & -5.5 \\
Hong Kong & -16.8 & -31.8 \\
Australia & -15.2 & 0.6 \\
Russia & -14.6 & 17.3 \\
\hline
\end{tabular}

Compiled according to the customs of China.

United States, which caused a collapse in the labor market in spring 2020 and a sharp deterioration in the country's economic prospects. Meanwhile, to combat the infection in the United States, supplies of sanitary equipment and active ingredients of pharmaceuticals from China (for many of which the duties under the Agreement have been increased) have become vital; note that they are also made with the participation of American entrepreneurs. Some of them were delivered to the United States as humanitarian aid from Chinese companies. By the end of April, China had shipped almost 3.5 bln medical masks, $300 \mathrm{mln}$ pairs of gloves, about 6000 ventilators, etc. Spending five times more money on health care, the United States, as it turns out, is inferior to China in the production of the necessary protective equipment and the training of medical personnel for emergencies.

The United States' vulnerability caused a paradoxical reaction in April: the media and some US officials demanded that China recover damages allegedly caused to the Americans by hiding information about coronavirus. Such cheating can be attributed to the indirect effects of the trade war, constantly fueling anti-Chinese sentiment in American society. According to Pew Research Center polls, $66 \%$ of the Americans expressed a negative attitude towards China in March 2020, compared to 55\% in 2016 and $47 \%$ in 2017, when Trump took power [19].

\section{OVERCOMING THE RECESSION}

Against the background of the epidemic, the fall in China's GDP in the first quarter of this year amounted to $6.8 \%$, but in March the situation began to improve. In February-April, China, having overcome the epidemic before other countries, began to restore its economy. Recall that the economic situation in the country was also affected by other problems: in particular, as a result of the outbreak of the African plague in 
2019 , the number of pigs and meat production had decreased by more than $20 \%$, and prices for all livestock products had increased significantly; owing to sanitary measures, prices for vegetables rose sharply because farmers in many provinces could not get to city markets. This exacerbated the effects of the recession in the economy and exports, determined first by the shutdown of some enterprises and, then, by a reduction in foreign orders. Tariff barriers in the United States also played a negative role, the immediate importance of which, however, started to decrease owing to the general decline in demand in the American economy, which began in March-April.

Let us repeat that, already in March 2020, there appeared the first signs of an improvement in the Chinese economy. Normalization in food supply led to a decrease in the consumer price index from $5.2 \%$ in February (on an annualized basis) to $4.3 \%$ in March, and in food prices, from $21.9 \%$ to $18.3 \%$. By the end of the month, 95-99\% of wholesale food markets and chain stores had resumed their work, restoring the sales volume of the previous year. The situation was worse in the trade in industrial goods, in which the sales amounted to half of the level for last year. By the end of the month, $80 \%$ of catering establishments and $60 \%$ of hotels had opened [20].

Despite the tense economic situation inside the country and adverse external conditions, the Chinese leadership decided in a timely manner on a strategy to overcome the recession. In his speech at a government meeting on March 12, Prime Minister Li Keqiang emphasized that the main thing now was not growth but the employment problem [21], and later Xi Jinping also confirmed the key importance of this parameter in the country's economic policy for the near future. Judging by the measures already taken, Beijing has decided so far not to resort to an overlarge injection of loans into the economy (although the monetary policy softened significantly in the last months of 2019 and at the beginning of 2020: the basic interest rates and reserve ratio were reduced several times). Government spending, including targeted assistance to the poorest segments of the population, has been increased, and the liberalization of working conditions in China for foreign capital continues.

This is an important difference from the way to overcome the recession that threatened in 2009-the way that Chinese economists subsequently dubbed "irrigation with big water," referring to the massive injection of money into the economy. In addition to positive consequences, this tactic also had a number of long-term negative effects, such as financial bubbles and bad debts. Recall that, during the previous crisis, China also faced a sharp drop in demand for export products: in the first half of 2009, exports decreased by $25-27 \%$, and by the end of the year, by $16 \%$, including by $12.5 \%$ to the United States. However, neither this nor the reduction in exports in 2015 and 2016 had an excessive negative impact on economic growth. Today, the Chinese economy is even less dependent on external factors and can more easily bear their deterioration. ${ }^{2}$ The Chinese leadership is much more concerned about the internal situation.

To understand the steps taken and possible actions of the Chinese authorities to overcome the recession, we should dwell on the basic features of the Chinese economy and the changes that have occurred in the past ten years and especially in the years of the thirteenth five-year plan (2016-2020). Table 4 clearly shows that services have become the leading sector of the country's economy, although their share is still significantly lower than in most developed and developing countries. Apparently, this, as well as the traditional thrift of the Chinese, explains the still relatively timid tread of the consumer revolution as an engine of development. As a result, economic growth is still largely, albeit ever less, provided by investment and credit. Investment efficiency is increasing (Table 5), so Chinese leaders are clearly not inclined to change the overall picture of the relative balance of economy and finance through significant credit pumping.

Despite the urgency of internal measures to overcome the recession caused by the epidemic, the need has ripened for a radical improvement in the international situation. Chinese leaders of various ranks have time and again offered the world community assistance and joint action to curb the virus, emphasizing the importance of common efforts to get out of the recession. Trade wars in such circumstances are an inadmissible luxury. It seems that the understanding of this simple truth is gradually spreading from the business community to the heights of the political Olympus of the United States. After the signing of the January agreement, Trump authorized, in particular, the sale of high-tech General Electric aircraft engines to China, extended the permission on the supplies of microchips to Huawei, etc. Prior to these steps, a former economic adviser to J. Biden, J. Bernstein, said that if the US presidential candidate from the Democratic Party won the election in 2020, he would be expected to abandon the trade war with China on day one of his government [22].

However, it seems that Beijing is not very much interested in the games around the figure of a future occupant of the White House. Another point is important: in the current difficult conditions, there is no doubt that China will continue the policy of favoring business, both its own and that of other countries, including American, whose positions, by the way, are quite strong in the country's export sector. Beijing clearly draws a dividing line between US companies

\footnotetext{
2 In 2010-2019, China's nominal GDP grew from about 40 to 100 trillion yuan, or 2.5 times. Its exports over the same period increased from $\$ 1.58$ trillion to $\$ 2.5$ trillion, or less than 1.6 times. The yuan rate against the US dollar in 2010 and 2019 remained approximately the same. Thus, the country's dependence on its foreign sales decreased significantly.
} 
Table 4. Structural indicators of China's economy in 2010 and $2019, \%$ of GDP

\begin{tabular}{l|r|r}
\hline \multicolumn{1}{c|}{ Industries } & 2010 & 2019 \\
\hline Agriculture & 9.3 & 7.1 \\
Industry as a whole & 46.5 & 39.0 \\
Services & 44.2 & 53.9 \\
Savings & 51.4 & 43.9 \\
Accrual & 47.7 & 43.6 \\
Household consumption & 35.6 & 40.0 \\
Government consumption & 12.9 & 14.9 \\
Bank loans & 142.0 & 218.0 \\
M2 aggregate & 176.1 & 200.1 \\
Private deposits & 77.1 & 82.9 \\
\hline
\end{tabular}

Compiled by Key Indicators for Asia and the Pacific 2019. Asian Development Bank.

https://www.adb.org/sites/default/files/publica-

tion/521981/ki2019.pdf. Cited February 15, 2020, pp. 100, 104, 124, 128; data of the National Bureau of Statistics of China.

Table 5. GDP, investment, and labor productivity growth in 2016-2019, \%

\begin{tabular}{l|c|c|c|c}
\hline \multicolumn{1}{c|}{ Indicators } & 2016 & 2017 & 2018 & 2019 \\
\hline GDP & 6.7 & 6.8 & 6.6 & 6.1 \\
Fixed asset investment & 7.9 & 7.0 & 5.9 & 5.1 \\
Labor productivity & 6.4 & 6.7 & 6.6 & 6.2 \\
\hline
\end{tabular}

Data of the National Bureau of Statistics of China.

and the Washington establishment, as if ignoring sometimes their close interaction, including that directed against Chinese interests. Having indicated at the end of May 2019 the intention to create its list of unreliable American companies, organizations, and individuals, China has not yet taken restrictive measures in relation to American business. The general approach was outlined by the Chinese expert in international relations Wang Jixing: "As the US government is restricting Huawei, Huawei should insist on cooperating with US enterprises... There is no need to ban Apple in China" [23]. Interestingly, this position materialized in April 2020, when the Chinese press announced an international cooperation project to create an information center in Ulanqab (Inner Mongolia) with the participation of Huawei, Alibaba, and Apple [24].

At the same time, orientation at a constructive dialogue with foreign business does not change Beijing's basic approach, which was outlined back in the mid1980s. It implies that, in order to develop all parts of production and construction quickly, it is necessary to develop economic cooperation and technical exchange with foreign countries on the basis of the steady implementation of the principle of indepen- dence, self-reliance, equality, mutual benefit, and compliance with agreements [25, p. 25]. Over time, self-reliance led to the formation in China of the largest and most diversified industrial system in the world. ${ }^{3}$ It can maintain the development potential even in conditions of semi-isolation, and the development of ties with the outside world, as Chinese reform strategists wrote, implies an even greater expansion of ties between different regions within the country [25, p. 27]. The domestic market, of course, will help the PRC this time again, as well as the excellent transport and information infrastructure created at the beginning of the 21 st century.

The indispensability of an economically strong state-during the exacerbations of the trade war with the United States, the Chinese often appealed to the Charter of Economic Rights and Obligations of the States, adopted by the United Nations in 1974 [27]seems especially obvious during the crisis periods of history. Part of the state tasks at such times can be taken over by large business. The companies Alibaba and Tencent in March 2020 eagerly responded to the request of the Chinese leadership to employ 55000 retired servicemen of the People's Liberation Army of China. In our time, this is a completely natural event for the Celestial Empire.

$* * *$

Noteworthy is one significant bias in American scientific publications about the US trade war with China and the relations of the two countries in recent years. Unfortunately, there is a clear predominance of works on conflicts, crises in relations, struggle for world hegemony, etc. A special place in this body of literature is occupied by the openly amateurish creations of Navarro [28] and conflict-permeated writings by M. Pillsbury [29], G. Allison [30], and M. Beckley [31]. In the background and outside the scope of attention of present-day American politicians are much more balanced works by world economists D. Rodrik [32], S. Roach [33], and M. Witt [34], as well as associates of the Peterson Institute for International Economics in Washington [35].

Back in 2014, Roach predicted the possibility of a trade war between the United States and China as the least desirable option for the evolution of bilateral relations. As a way to improve them and get rid of imbalances, he recommended increasing productive investment in the United States and accelerating the development of services and consumption in China. As we tried to show, China largely took these tips into

\footnotetext{
${ }^{3}$ International statistics on trade in value added shows that China is the only country that managed to increase its share in industrial exports (by 12\% from 1995 to 2014). In 2000-2014, China was also the only country in which the share of labor income in value added increased [26, p. vi]. From 2009 to 2019, according to Chinese statistics, the share of fully manufactured exported industrial products in the country increased from 45 to $60 \%$.
} 
account and has to a considerable extent overcome certain production hypertrophy. Unfortunately, there are far fewer positive changes in the United States.

In conclusion, we give our final comment concerning the important difference in views on the economy between the Americans and the Chinese. The former are guided by their monetary understanding (in the Agreement, they denote in cash even the volume of deliveries of fuel and food products). The Chinese, who are historically accustomed to the situation of a constant shortage of vital resources, are more inclined to consider economic activity as satisfying the vital needs of the population; hence, their steady habit of evaluating and planning things in physical terms. Of course, there is no insurmountable wall between these two views, but there is, as they say, a nuance that is important for healing and putting our planet in order.

\section{REFERENCES}

1. Economic and Trade Agreement between the Government of the United States of America and the Government of the People's Republic of China. January 15, 2020. https://ustr.gov/sites/default/files/files/agreements/phase\%20one\%20agreement/Economic And Trade Agreement Between The Unite d_States_And_China_Text.pdf. Cited April 19, 2020.

2. National Security Strategy of the United States of America. December 2017. https://www.whitehouse.gov/wp-content/uploads/2017/12/NSS-Final12-18-2017-0905.pdf. Cited April 15, 2020.

3. Findings of the Investigation into China's Acts, Practices, and Policies Related to Technology Transfer, Intellectual Property, and Innovation under Section 301 of the Trade Act of 1974. United States Trade Representative. March 2018. https://ustr.gov/sites/default/files/Section\%20301\%20FINAL.PDF. Cited March 10, 2020.

4. How China's Economic Aggression Threatens the Technologies and Intellectual Property of the United States and the World. White House Office of Trade and Manufacturing Policy. June 2018. https://www.whitehouse.gov/wp-content/uploads/2018/06/FINALChina-Technology-Report-6.18.18-PDF.pdf. Cited March 10, 2020.

5. 2017 Report to Congress on China's WTO Compliance. United States Trade Representative. January 2018. https://ustr.gov/sites/default/files/files/Press/Reports/China\% $202017 \% 20$ WTO\%20Report.pdf. Cited March 10, 2020.

6. 2018 Report to Congress on China's WTO Compliance. United States Trade Representative. January 2019. https://ustr.gov/sites/default/files/2018-USTR-Report-to-Congress-on-China\%27s-WTO-Compliance.pdf. Cited March 10, 2020.

7. Foreign Investment Risk Review Modernization Act of 2018. August 2018. https://home.treasury.gov/sites/default/files/2018-08/The-Foreign-Investment-RiskReview-Modernization-Act-of-2018-FIRRMA_0.pdf. Cited August 8, 2019.
8. The Facts and China's Position on China-US Trade Friction. Information Office of the State Council. The People's Republic of China. September 2018. http://english.gov.cn/archive/white_paper/2018/09/26/content_281476319220196.htm. Cited April 19, 2020.

9. Civil Code of the Russian Federation (Part four) of December 18, 2006, No. 230-FZ. http://www.consultant.ru/document/cons_doc_LAW_64629/. Cited May 2, 2020.

10. Defend Trade Secrets Act of 2016 (Public Law No. 114-153). https://wipolex.wipo.int/en/legislation/details/16087. Cited May 4, 2020.

11. Code of Federal Regulations. 19 CFR 201.6-Confidential business information. https://www.govinfo.gov/app/details/CFR-2011-title19-vol3/CFR-

2011-title19-vol3-sec201-6/summary. Cited May 4, 2020.

12. Several Provisions on Prohibiting Infringements upon Trade Secrets. https://wipolex.wipo.int/en/legislation/details/6551. Cited May 4, 2020.

13. Law of the People's Republic of China Against Unfair Competition (promulgated by People's Republic of China Presidential Order No. 10 on September 2, 1993). https://wipolex.wipo.int/en/legislation/details/849. Cited May 5, 2020.

14. Central Intelligence Agency, The World Factbook Field Listing: Exports-Commodities

. https://www.cia.gov/library/publications/the-worldfactbook/. Cited May 6, 2020.

15. 2019 Report to Congress of the U.S.-China Economic and Security Review Commission. https://www.uscc.gov/sites/default/files/2019-11/2019\%20Executive\%20Summary.pdf. Cited April 20, 2020.

16. https://fred.stlouisfed.org/series/MANEMP. Cited April 20, 2020.

17. Key Indicators for Asia and the Pacific 2019. Asian Development Bank. https://www.adb.org/sites/default/files/publication/521981/ki2019.pdf. Cited February 15, 2020.

18. C. Zhou and F. Bermingham, China-based firms look to obscure tariff loophole to dodge trade war, but US customs is cracking down. https://www.sc$\mathrm{mp}$.com/economy/china-economy/article/3024108/china-based-firms-look-obscure-tariffloophole-dodge-trade. Cited November 12, 2019.

19. https://cdn.i-scmp.com/sites/default/files/d8/images/methode/2020/04/22/8c85a2ba-834e-11ea-88632139a14b0dea_972x_001843.jpg. Cited April 22, 2020.

20. http://www.ecns.cn/news/economy/2020-03-29/detail-ifzuwwmz9244514.shtml. Cited April 8, 2020.

21. http://www.gov.cn/premier/2020-03/12/content_5490395.htm. Cited March 15, 2020.

22. J. Bernstein, Trump's China Trade War Is Failing. Democrats Should Campaign Against It. https://www.nytimes.com/2019/12/11/opinion/trump-china-trade.html. Cited December 12, 2019.

23. China should cooperate with all nations, not be put off by US' aggressive trade war tactics, academic says. https://www.scmp.com/news/china/diplomacy/arti- 
cle/3014406/china-should-cooperate-all-nations-notbe-put-us-aggressive. Cited May 28, 2019.

24. Inner Mongolia to invest 130 billion yuan in major infrastructure projects. http://innermongolia.chinadaily.com.cn/2020-04/17/c_471844.htm. Cited April 18, 2020.

25. "Resolution of the Central Committee of the CPC on the reform of the economic system. October 23, 1984," in The Economic reform in PRC: Transformations in the City 1979-1984: Documents (Vostochnaya Literatura, Moscow, 1994) [in Russian].

26. Trade and Development Report 2018: Power, Platforms and the Free Trade Delusion. UNCTAD, 2018. https://unctad.org/en/PublicationsLibrary/tdr2018_en.pdf. Cited May 28, 2019.

27. U.S.-China Economic and Security Review Commission. Economics and Trade Bulletin. June 6. 2019. https://www.uscc.gov/sites/default/files/Research/June\%202019\%20Trade\%20Bulletin.pdf. Cited July 18, 2019.

28. P. Navarro, The Coming China Wars: Where They Will Be Fought and How They Can Be Won (FT Press, 2008); P. Navarro and G. Autry, Death by China: Confronting the Dragon-A Global Call to Action (Pearson, 2011).
29. M. Pillsbury, The Hundred Year Marathon: China's Secret Strategy to Replace America as the Global Superpower (St. Martin Griffin, New York, 2015).

30. G. Allison, Destined for War: Can America and China Escape Thucydides's Trap? (Houghton Mifflin Harcourt, Boston, 2017).

31. M. Beckley, Unrivaled: Why America Will Remain the World's Sole Superpower (Cornell Univ. Press, 2018).

32. D. Rodrik, Straight Talk on Trade: Ideas for a Sane World Economy (Princeton Univ. Press, 2017).

33. S. Roach, Unbalanced: The Codependency of America and China (Yale Univ. Press, 2014).

34. M. Witt, "De-globalization: Theories, predictions, and implications for international business research," J. Int. Bus. Stud. 50 (7), 1053-1077 (2019).

35. F. Bergsten, China and the United States: Trade Conflict and Systemic Competition. Policy Brief, October 2018. https://piie.com/publications/policy-briefs/china-and-united-states-trade-conflict-and-systemiccompetition. Cited April 18, 2020.

Translated by B. Alekseev 